\title{
Sensitive spectrophotometric assay of simvastatin in pharmaceuticals using permanganate
}

\author{
Kalsang Tharpa ${ }^{1}$, Kanakapura Basavaiah ${ }^{1, *}$, Nagaraju Rajedraprasad ${ }^{1}$, \\ Kanakapura Basavaiah Vinay ${ }^{1}$, Salmara Ganeshbhat Hiriyanna ${ }^{2}$
}

${ }^{1}$ Department of Chemistry, University of Mysore, ${ }^{2}$ Process Analytical Laboratory, Advinus Therapeutics

\begin{abstract}
Two simple, sensitive, selective and inexpensive spectrophotometric methods are described for the determination of simvastatin (SMT) in bulk drug and in tablets using permanganate as the oxidimetric reagent. In method A, SMT is treated with a measured excess of permanganate in acetic acid medium and the unreacted oxidant is measured at $550 \mathrm{~nm}$, whereas in method B the reaction is carried out in alkaline medium and the resulting manganate is measured at $610 \mathrm{~nm}$. In method A, the amount of permanganate reacted corresponds to the SMT content and the absorbance is found to decrease linearly with the concentration; and in method B, the absorbance increases with concentration. The working conditions of assays were optimized, and the methods were validated according to the current ICH guidelines. Under optimum conditions, SMT could be assayed in the concentration ranges, $1.47-17.67 \times 10^{-5}$ and $2.27-27.18$ $\mathrm{x} 10^{-6} \mathrm{~mol} / \mathrm{L}$ by method A and method B, respectively. The calculated molar absorptivities are $3.2 \times 10^{3}$ and $2.5 \times 10^{4} \mathrm{~L} / \mathrm{mol} / \mathrm{cm}$ for method A and method B, respectively with corresponding Sandell sensitivity values of 0.0387 and $0.0178 \mu \mathrm{g} / \mathrm{cm}^{2}$. The limits of detection (LOD) and quantification (LOQ) have also been reported. Accuracy and precision for the assay were determined by calculating the intra-day and inter-day at three concentrations; the intra-day RSD was $<2 \%$ and the accuracy was better than $2.15 \%$ (RE). The methods were applied successfully for the determination of SMT in tablet dosage form with a high percentage of recovery, good accuracy and precision, and without measurable interference by the excipients. The accuracy was further ascertained from placebo and synthetic mixture analysis and also from the spike-recovery method.
\end{abstract}

Uniterms: Simvastatin assay. Spectrophotometry. Permanganate. Pharmaceutical products.

\begin{abstract}
Dois métodos espectrofotométricos simples, sensíveis, seletivos e baratos são descritos para a determinação de sinvastatina (SMT) a granel e em comprimidos, utilizando permanganato como reagente oxidimétrico. No método A, a SMT é tratada com excesso conhecido de permanganato em meio de ácido acético e o oxidante que não reage é medido a $550 \mathrm{~nm}$, enquanto no método $\mathrm{B}$, a reação é efetuada em meio alcalino e o manganato resultante é medido a $610 \mathrm{~nm}$. No método A, a quantidade de permanganato que reage corresponde ao conteúdo de $S M T$ e a absorbância diminui linearmente com o aumento da concentração; no método B, a absorbância aumenta com o aumento da concentração. As condições de trabalho do ensaio foram otimizadas e os métodos, validados de acordo com as normas do ICH. Sob condições

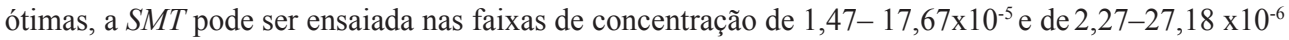
$\mathrm{mol} / \mathrm{L}$ pelo método A e B, respectivamente. As absortividades molares calculadas são $2 \times 10^{3} \mathrm{e} 2,5 \times 10^{4}$ $\mathrm{L} / \mathrm{mol} / \mathrm{cm}$, respectivamente, para os métodos A e B, com os valores correspondentes de sensibilidade de Sandell de 0,0387 e $0,0178 \mu \mathrm{g} / \mathrm{cm}^{2}$. Os limites de detecção (LOQ) também foram relatados. A exatidão e a precisão do ensaio foram determinadas pelo cálculo de três concentrações intra- e inter-dia; a RSD intra-dia foi $<2 \%$ e a exatidão foi melhor que $2,15 \%$ (RE). Os métodos foram aplicados com sucesso à determinação de $S M T$ em comprimidos com alta porcentagem de recuperação, boa exatidão e precisão e sem interferência mensurável dos excipientes. A exatidão foi posteriormente determinada no placebo e na mistura sintética e, também, pelo método de spike recovery.
\end{abstract}

Unitermos: Sinvastatina/ensaio. Espectrofotometria. Permanganato. Produtos farmacêuticos.

\footnotetext{
*Correspondence: K. Basavaiah. Department of Chemistry, University of Mysore, Manasagangothri, Mysore-570006, India. Fax: 0091-821-2421263, 2516133).E-mail: basavaiahk@yahoo.co.in
} 


\section{INTRODUCTION}

Simvastatin (SMT), chemically known as $(1 \mathrm{~S}, 2 \mathrm{~S}, 8 \mathrm{~S}$, $8 \mathrm{aR})-1,2,6,8,8 \mathrm{a}-$ hexahydro-1-(2-((2R, 4R)-tetrahyro-4hydroxy-6-oxo-2H-pyran-2-yl)-2,6-dimethylnapthalen-8yl 2,2-dimethylbutanoate (Figure 1), belongs to the group of cholesterol-lowering lactones known as statins which, in 2007, were identified as being among the most widely prescribed drugs in the world. Statins lower cholesterol by inhibiting the synthesis of movalinic acid, which is the key precursor in cholesterol synthesis. SMT has been shown to be effective as an antilipemic agent. It is administered as a pro drug, and in the liver it is hydrolysed to the $\beta$-hydroxy acid form (Mc Evoy, 2002). The drug is officially listed in the 2004 United States Pharmacopoeia and the official method of its determination is high-performance liquid chromatography (The United State Pharmacopoeia, 2002). Various other methods such as UV-spectrophotometry (Erk, 2002; Xu, 2001; Zhonghong, Shurong 2000; Wang, Asgharnejad, 2000; Arayne et al., 2007; Carlcucci, Mazzeo, 1992), HPLC (Carlcucci, Mazzeo, 1992; Jianwei, Ying, 2005; Ali et al., 2006; Carolina et al., 2004, Xan et al., 2000; Wang, 2000), HPTLC (Chandhari et al., 2007), micellar electrokinetic chromatography (Srinivasu et al., 2002) and voltammetry (Coruh, Ozkan, 2006) have been reported for the assaying of SMT in pharmaceuticals. There is only one report on the use of visible spectrophotometry which describes three methods (Saradhi et al. 2007) for $S M T$. One procedure is based on the reduction of iron (III) by SMT to iron (II) and subsequent formation of prussian blue with ferricyanide measurable at $730 \mathrm{~nm}$. In the other two procedures, the iron (II) formed is chelated with 1,10-phenanthroline or 2,2'-bipyridine followed by measurement of absorbance at 480 or $490 \mathrm{~nm}$. The present paper describes two visible spectrophotometric methods using $\mathrm{KMnO}_{4}$ as an oxidizing agent in both acid and basic medium. Simplicity, sensitivity wide linear ranges, mild experimental conditions and above all cost-effectiveness

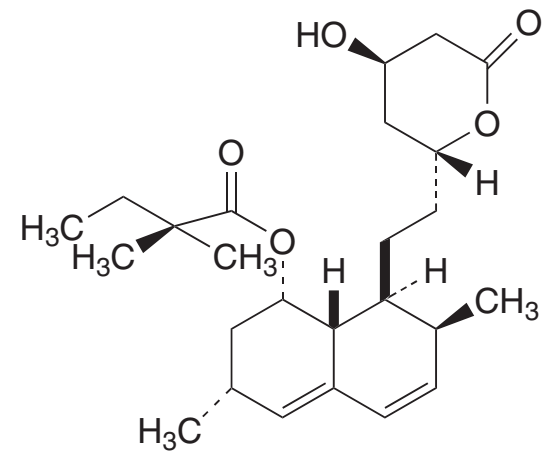

FIGURE 1 - Structure of simvastatin. characterize the proposed methods. Further, the methods were found to possess adequate accuracy and precision.

\section{EXPERIMENTAL}

\section{Apparatus}

A Systronics model 106 digital spectrophotometric with 1-cm matched quartz cells was used for all absorbance measurements.

\section{Reagents and materials}

All chemicals used were of analytical reagent grade and distilled water was used to prepare all solutions. Potassium permanganate $\left(1 \times 10^{-2} \mathrm{~mol} / \mathrm{L}\right)$ was prepared by dissolving about $0.395 \mathrm{~g}$ of the chemical (Merck, Mumbai, India) in water and diluting to $250 \mathrm{~mL}$; and standardized using H.A Bright's procedure (A.I. Vogel, $3^{\text {rd }}$ edition, 1961 , p. 280). It was further diluted to $3.164 \times 10^{-3} \mathrm{~mol} / \mathrm{L}$ $\mathrm{KMnO}_{4}$ for method A and $6.328 \times 10^{-3} \mathrm{~mol} / \mathrm{L} \mathrm{KMnO}_{4}$ for method B. Acetic acid (3:2) was prepared by diluting concentrated acetic acid (Merck, Mumbai, India, Sp. gr. 1.05) appropriately with water. Sodium hydroxide solution $(0.3$ and $0.5 \mathrm{~mol} / \mathrm{L}$ ) was prepared by dissolving the chemical (Merck, Mumbai, India) in water. Pharmaceutical grade $S M T$, certified to be $99.88 \%$ pure, was kindly provided by Jubiliant Organosis, Nanjangud, India, as a gift and was used as received. A $2.944 \times 10^{-3} \mathrm{~mol} / \mathrm{L} S M T$ was prepared by dissolving $32.5 \mathrm{mg}$ of $S M T$ in $3: 2$ acetic acid and made up to $250 \mathrm{~mL}$ with the same acid used for method A. A $9.059 \times 10^{-5} \mathrm{~mol} / \mathrm{L} S M T$ was prepared by dissolving $10 \mathrm{mg}$ of $S M T$ in $0.3 \mathrm{~mol} / \mathrm{L} \mathrm{NaOH}$ with the aid of heat and made up to $250 \mathrm{~mL}$ with $0.3 \mathrm{~mol} / \mathrm{L} \mathrm{NaOH}$ and used in method B. Tablets containing SMT such as Zosta (USV Ltd, India) and Simvas (Micro labs Ltd, India) were purchased from the local market.

\section{METHODS}

\section{Method A}

Different aliquots of standard solution $(0.5-6.0 \mathrm{~mL}$, $\left.2.944 \times 10^{-4} \mathrm{~mol} / \mathrm{L}\right)$ of pure $S M T$ were transferred into a series of $10 \mathrm{~mL}$ calibrated flasks by means of micro burette and the total volume was adjusted to $6.0 \mathrm{~mL}$ with $3: 2$ acetic acid. A volume of $1 \mathrm{~mL}$ of $3.164 \times 10^{-3} \mathrm{~mol} / \mathrm{LKMnO}_{4}$ was added to each flask accurately, and kept aside for $10 \mathrm{~min}$ with occasional swirling before diluting to the mark with water. The absorbance was recorded at $550 \mathrm{~nm}$ against a water blank. 


\section{Method B}

Into a series of $10 \mathrm{~mL}$ calibrated flasks, $0.25-3.0 \mathrm{~mL}$ of $9.059 \times 10^{-5} \mathrm{~mol} / \mathrm{L}$ pure $S M T$ solution were buretted and the total volume was made up to $3.0 \mathrm{~mL}$ with $0.3 \mathrm{~mol} / \mathrm{L}$ $\mathrm{NaOH}$. To each flask was added $1 \mathrm{~mL}$ of $0.5 \mathrm{~mol} / \mathrm{L} \mathrm{NaOH}$ followed by $1 \mathrm{~mL}$ of $6.328 \times 10^{-3} \mathrm{~mol} / \mathrm{L} \mathrm{KMnO}_{4}$ solution. The flasks were kept aside for 20 min with occasional shaking and the volume was made up to the mark with water. The absorbance was recorded at $610 \mathrm{~nm}$ against the reagent blank.

\section{Assay procedure for tablets}

Twenty tablets were accurately weighed and powdered. A portion of tablet powder equivalent to $20 \mathrm{mg}$ of $S M T$ was accurately weighed into a $100 \mathrm{~mL}$ calibrated flasks, $40 \mathrm{~mL}$ of 3:2 acetic acid was added and shaken for $20 \mathrm{~min}$. Then, the volume was made up to the mark with the same acid, mixed well and filtered using a Whatman No. 42 filter paper. First, a $10 \mathrm{~mL}$ portion of the filtrate was rejected and a convenient aliquot (around 2 or $3 \mathrm{~mL}$ ) was subjected to analysis by the procedure described under method A. Another portion of the tablet powder containing $20 \mathrm{mg}$ of $S M T$ was accurately weighed and transferred to a separating funnel containing about $40 \mathrm{~mL}$ of water and mixed. The content was extracted with $5 \times 5 \mathrm{~mL}$ portions of chloroform, where the combined organic layer was dried over anhydrous sodium sulphate, and transferred into a dry beaker and evaporated to dryness in a water bath. The residue was dissolved in $0.3 \mathrm{~mol} / \mathrm{L} \mathrm{NaOH}$ with the aid of heat and transferred to a $100 \mathrm{~mL}$ volumetric flask and diluted to the mark with $0.3 \mathrm{~mol} / \mathrm{L} \mathrm{NaOH}$. The solution was diluted to $9.059 \times 10^{-5} \mathrm{~mol} / \mathrm{L} S M T$ with the same alkali solution and the analysis was completed by following the procedure given under method B.

\section{RESULTS AND DISCUSSION}

The methods are based on the oxidation of SMT by $\mathrm{KMnO}_{4}$ in either acid or alkaline medium followed by measurement of the residual permanganate at $550 \mathrm{~nm}$ in method A or the reduced manganate at $610 \mathrm{~nm}$ in method B. The possible reaction scheme is given in Figure 2.

\section{Optimization of experimental conditions}

In method $\mathrm{A}$, when a fixed concentration of permanganate was reacted with increasing concentrations of SMT in acetic acid medium, there occurred a concomitant fall in the concentration of permanganate as revealed by the decreasing absorbance at $550 \mathrm{~nm}$ (Figure 3 and Figure 4), which served

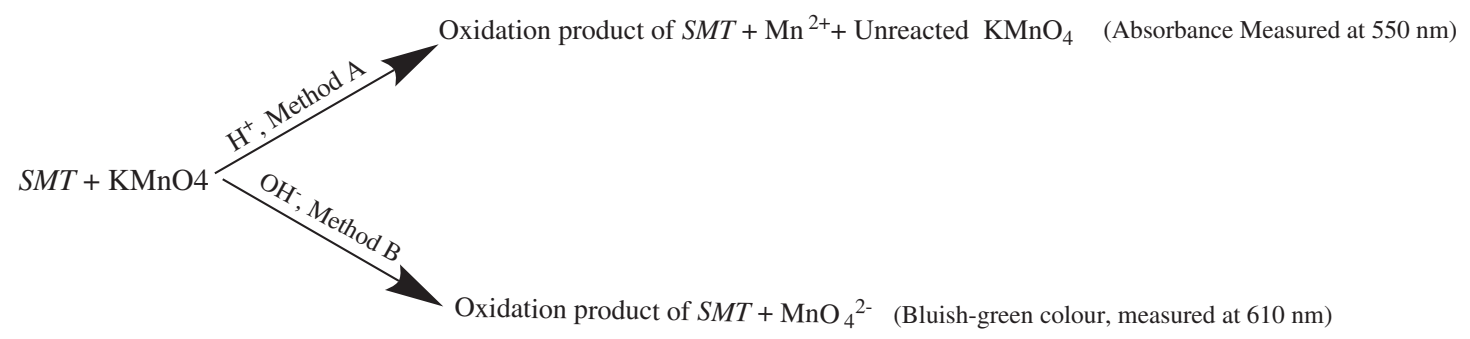

FIGURE 2 - Tentative reaction scheme.
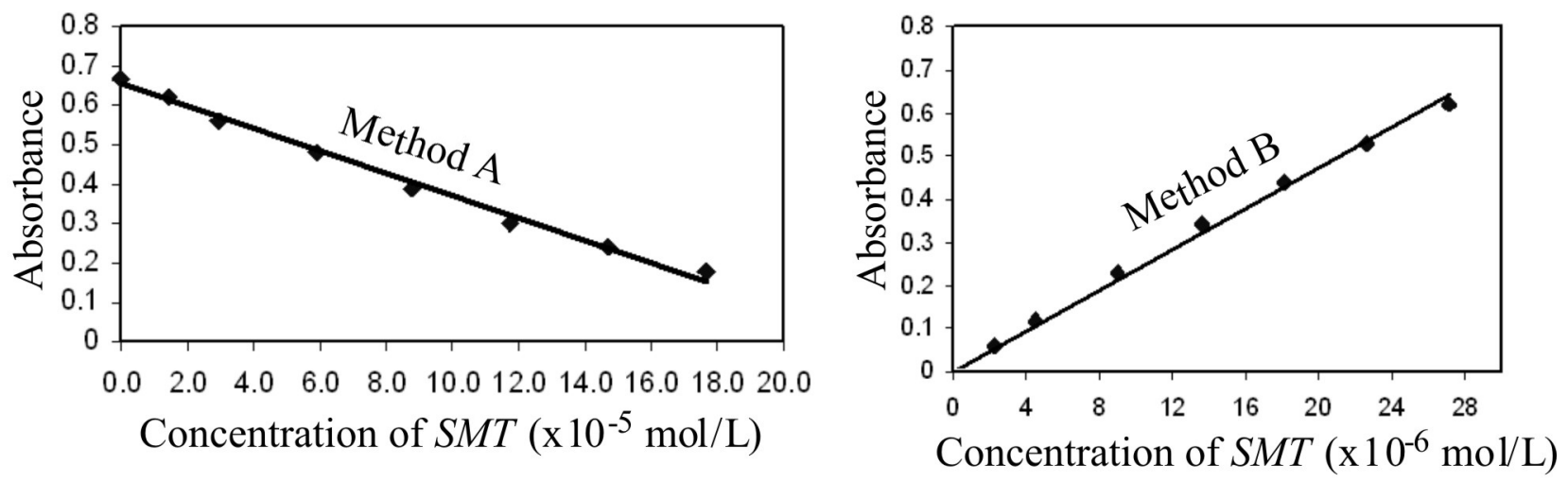

FIGURE 3 - Calibration curves for method A and method B. 


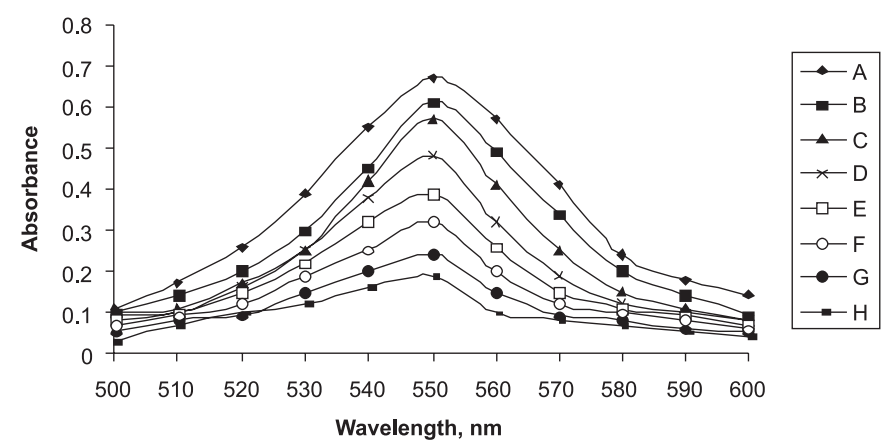

FIGURE 4 - Method A: Effect of SMT concentration on the absorbance of $3.164 \times 10^{-4} \mathrm{~mol} / \mathrm{L} \mathrm{KMnO}_{4}$ (A.0.0; B.1.47; C.2.94; D.5.89; E.8.83; F.11.78; G.14.72 and H.17.67 x 10 $10^{-5} \mathrm{~mol} / \mathrm{L}$ SMT).

as the basis for quantification. A preliminary experiment showed that permanganate can be determined up to $3.164 \mathrm{x}$ $10^{-4} \mathrm{~mol} / \mathrm{L}$ at $550 \mathrm{~nm}$ in the acid medium employed (Figure 5). Hence, different concentrations of $S M T$ were reacted with $1 \mathrm{~mL}$ of $3.164 \times 10^{-3} \mathrm{~mol} / \mathrm{LKMnO}_{4}$ to determine the concentration range over which $S M T$ could be determined. One $\mathrm{ml}$ of $3.164 \times 10^{-3} \mathrm{~mol} / \mathrm{L} \mathrm{KMnO}_{4}$ must be accurately added in all the reaction flasks since $\mathrm{KMnO}_{4}$ absorbs maximally at the analytical wavelength, and small changes in the volume of $\mathrm{KMnO}_{4}$ have a critical effect on the absorbance reading. The solvent used to dissolve $S M T$ was 3:2 acetic acid, and below this concentration of acetic acid, SMT remained insoluble. The same acid concentration was used as a reaction medium. There was no effect of increasing the concentration of acetic acid on the reaction parameters. To check the effect of acid concentration on the reaction, $1-5 \mathrm{~mL}$ of $1 \mathrm{~mol} / \mathrm{L} \mathrm{H}_{2} \mathrm{SO}_{4}$ was added to the fixed concentration of $S M T$ and $\mathrm{KMnO}_{4}$, and it was observed that there was absolutely no change in the absorbance. The effect of hydrochloric acid was not studied since $\mathrm{KMnO}_{4}$ being a strong oxidizing agent would react with $\mathrm{HCl}$ to liberate chlorine. The reaction between $S M T$ and $\mathrm{KMnO}_{4}$ in acetic acid medium was complete in $10 \mathrm{~min}$ (Figu-

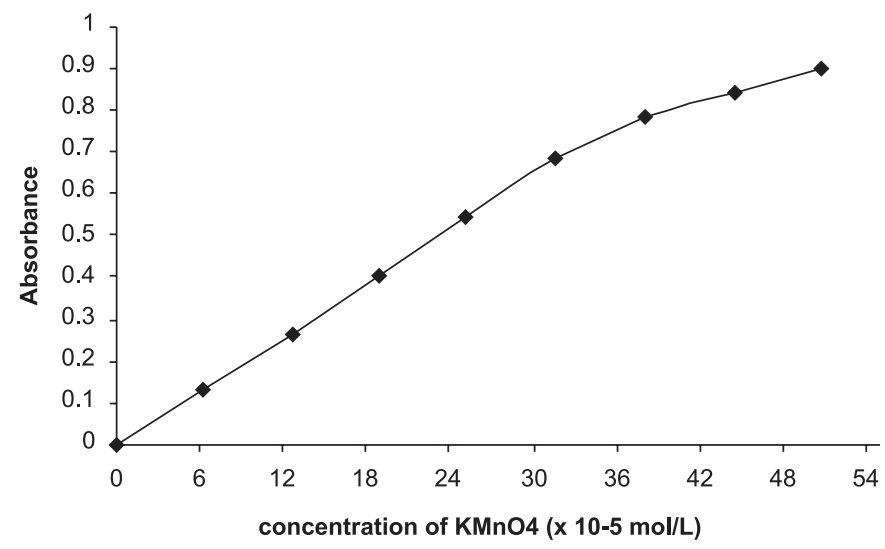

FIGURE 5 - Linear relation between absorbance at $550 \mathrm{~nm}$ and $\mathrm{KMnO}_{4}$ concentration. re 6), and the absorbance of the measured unreacted $\mathrm{KMnO}_{4}$ was found to be stable up to $40 \mathrm{~min}$ thereafter. Two blanks were prepared for the study. The reagent blank consisted of acid and permanganate showed maximum absorbance (equal to the intercept). A second blank in the absence of SMT and $\mathrm{KMnO}_{4}$ had negligible absorbance, and hence measurements were made against a water blank.

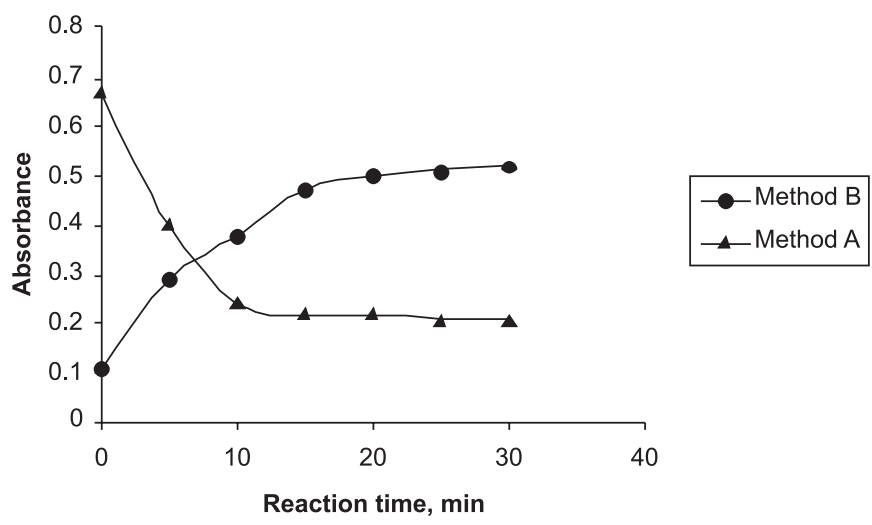

FIGURE 6 - Effect of reaction time between $\mathrm{KMnO}_{4}$ and $S M T$ in method $\mathrm{A}$ and method B.

Potassium permanganate quantitatively oxidizes $S M T$ in the presence of $\mathrm{NaOH}$ in method $\mathrm{B}$, resulting in the formation of a bluish-green color manganate ion (Mann and Sounders, 1974) which showed an absorption peak at $610 \mathrm{~nm}$ (Figure 7) and served as the basis for the calibration graph (Figure 3). Increase in the concentration of $\mathrm{KMnO}_{4}$ could enhance sensitivity of the method but the blank absorbance also increased concomitantly. The effect of $\mathrm{KMnO}_{4}$ concentration on the sensitivity of the reaction (Figure 8) was ascertained, and based on this the optimum concentration was fixed at $6.3278 \times 10^{-4} \mathrm{~mol} / \mathrm{L}$. Order of addition of $\mathrm{NaOH}$ is critical. When $\mathrm{NaOH}$ was added after the addition of $\mathrm{KMnO}_{4}$ to $S M T$, small brown particles with slightly greenish turbidity developed, possibly due to the formation of $\mathrm{MnO}_{2}$ in weak alkaline medium. One $\mathrm{mL}$ of

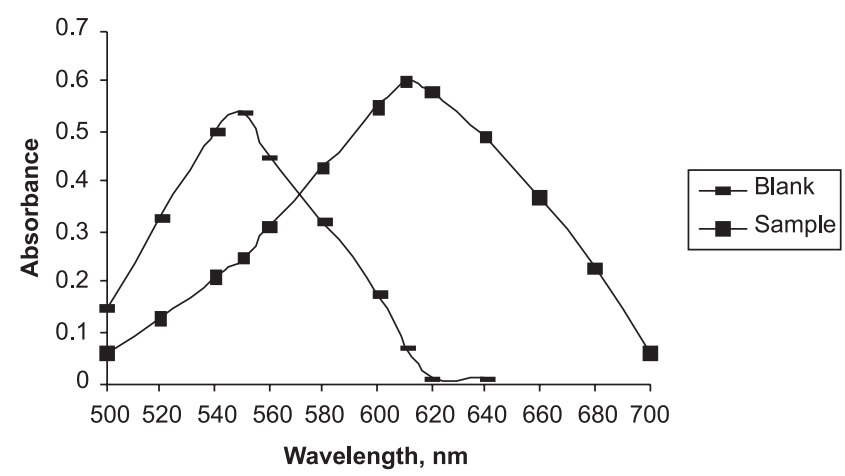

FIGURE 7 - Absorption spectra for method B. (Bluish green color produced for $27.18 \times 10^{-6} \mathrm{~mol} / \mathrm{L} S M T$ ) 


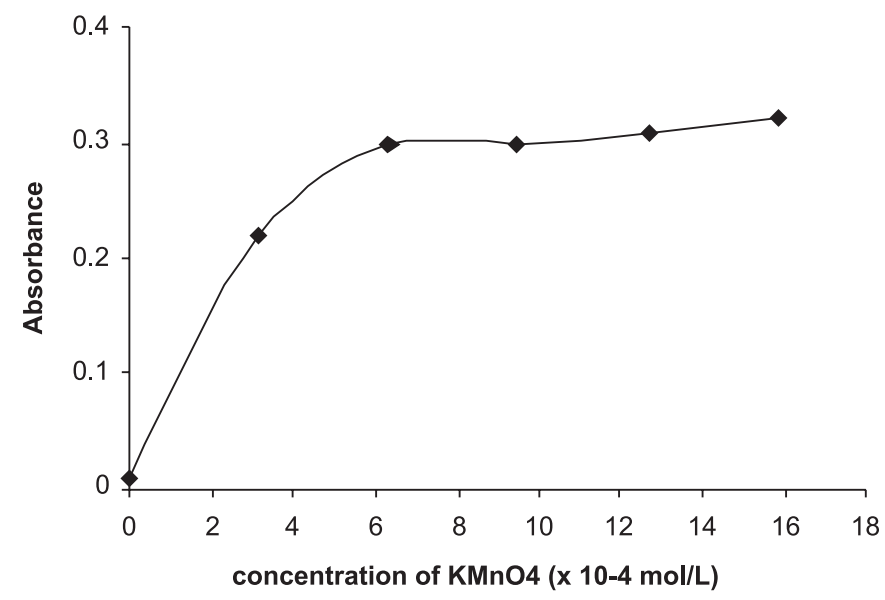

FIGURE 8 - Effect of $\mathrm{KMnO}_{4}$ concentration for method B.

$0.5 \mathrm{~mol} / \mathrm{L} \mathrm{NaOH}$ in the total volume of $10 \mathrm{~mL}$ was fixed because there was no appreciable effect on the reaction time and sensitivity when the volume of $0.5 \mathrm{~mol} / \mathrm{L} \mathrm{NaOH}$ was varied from $0.5-2.0 \mathrm{~mL}$. The reaction was complete in 20 min where the contact time was not critical and any delay up to $40 \mathrm{~min}$ had no effect on the absorbance. The absorbance of the measured color was constant for 50 min in the presence of unreacted $\mathrm{KMnO}_{4}$ and the reaction product. In both the methods, the reaction rate was not studied at higher temperature since both the reactions reached completion within a reasonable time. The Job's method of continuous variation was applied to establish the stoichiometric ratio of $S M T$ to $\mathrm{KMnO}_{4}$ in basic medium and was found to be 1: $4\left(S M T: \mathrm{KMnO}_{4}\right)$ (Figure 9).

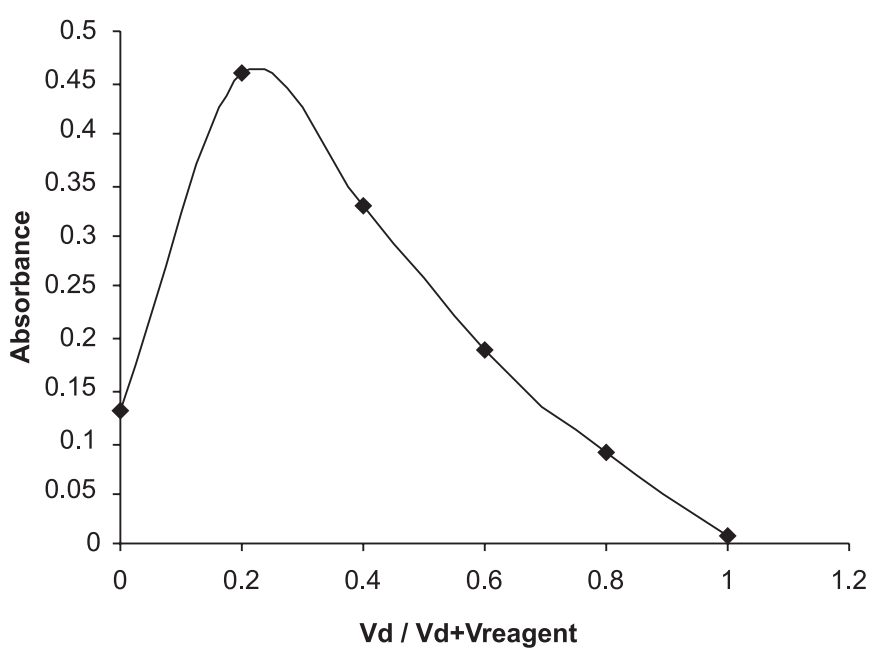

FIGURE 9 - Job's continuous variations plot.

\section{Analytical data}

A linear correlation was found between absorbance at $\lambda_{\max }$ and concentration of SMT in the ranges given in Table I. This correlation establishes an inverse relation between SMT and permanganate. This behavior was possible because the latter follows the Beer-Lambert's law. The inverse linear relationship in method $\mathrm{A}$ is described by the regression equation:

$$
\mathrm{Y}=\mathrm{a}-\mathrm{bX}
$$

(Where $\mathrm{Y}=$ absorbance of $1-\mathrm{cm}$ layer of solution; $\mathrm{a}=$

TABLE I - Regression and Analytical parameters

\begin{tabular}{lcc}
\hline Parameter & Method A & Method B \\
\hline$\lambda_{\text {max }}, \mathrm{nm}$ & 550 & 610 \\
Range concentration limits, $\mathrm{mol} / \mathrm{L}$ & $1.47-17.67 \times 10^{-5}$ & $2.27-27.18 \times 10^{-6}$ \\
Apparent molar absorptivity, $\mathrm{L} / \mathrm{mol} / \mathrm{cm}$ & $3.2 \times 10^{3}$ & $2.5 \times 10^{4}$ \\
Sandell sensitivity*, $\mu \mathrm{g} / \mathrm{cm}^{2}$ & 0.0387 & 0.0178 \\
Limit of detection, $\mathrm{mol} / \mathrm{L}$ & $3.13 \times 10^{-6}$ & $1.29 \times 10^{-6}$ \\
Limit of quantification, $\mathrm{mol} / \mathrm{L}$ & $1.04 \times 10^{-5}$ & $1.33 \times 10^{-6}$ \\
Regression equation, $\mathrm{Y}^{* *}$ & & \\
Intercept (a) & 0.6427 & 0.0209 \\
Slope (b) & -0.0062 & 0.0510 \\
Correlation coefficient, $(\mathrm{r})$ & -0.9961 & 0.9987 \\
$\mathrm{~S}_{\mathrm{a}}$ & 0.01601 & 0.01130 \\
$\mathrm{~S}_{\mathrm{b}}$ & 0.00025 & 0.00112 \\
\hline
\end{tabular}

${ }^{*}$ Is a sensitivity parameter in $\mu \mathrm{g} / \mathrm{cm}^{2} S M T$ corresponding to an absorbance of 0.001 measured in a cuvette of cross-sectional area $1 \mathrm{~cm}^{2}$ and $\mathrm{L}=1 \mathrm{~cm}$.

$\mathrm{Y}^{* *}=\mathrm{a} \pm \mathrm{bX}$, where $\mathrm{Y}$ is the absorbance and $\mathrm{X}$ concentration in mol/L; $\mathrm{S}=$ Standard deviation of intercept; $\mathrm{S}_{\mathrm{b}}=$ Standard deviation of slope. 
intercept; $b=$ slope and $X=$ concentration in $\mathrm{mol} / \mathrm{L}$ ). Regression analysis of the linear relation data using the method of least squares was performed to evaluate the slope (b), intercept (a) and correlation coefficient (r) for each system, and the values are presented in Table I. The optical characteristics such as range concentration limits, apparent molar absorptivity and Sandell sensitivity values of both methods are also given in Table I. The limits of detection (LOD) and quantification (LOQ) calculated according to ICH guidelines (1996) are also presented in Table I.

\section{Method Validation}

\section{Assay precision and accuracy}

The precision of the methods was calculated in terms of intermediate precision (intra-day and inter-day) (SHABIR, G.A, 2003). Three different concentrations of $S M T$ were analyzed in seven replicates during the same day (intra-day precision) and for five consecutive days (inter-day precision). The RSD (\%) values of intra-day and inter-day studies showed that the precision was good (Table III). The accuracy of an analytical method expresses the closeness between the reference value and the found value. Accuracy was evaluated as percentage relative error between the measured concentrations and concentrations taken for SMT (Bias \%). The results obtained are compiled in Table II and show that the accuracy is good.

\section{Method Selectivity}

Selectivity was evaluated by recovery studies. A synthetic mixture consisting of $20 \mathrm{mg}$ sodium alginate, $30 \mathrm{mg}$ magnesium stearate, $20 \mathrm{mg}$ lactose, $20 \mathrm{mg}$ acacia, $50 \mathrm{mg}$ talc and $30 \mathrm{mg}$ starch besides $20 \mathrm{mg}$ of $S M T$ was prepared and analyzed after extraction into acetic acid in method A, and into chloroform in the case of method B, as described under analysis of tablets. The percent recovery of $S M T$ was $98.64 \pm 0.86$ and $96.58 \pm 0.63$ for method A and method B, respectively. This confirms the selectivity of methods under the optimized conditions.

\section{Placebo analysis}

Placebo analysis was carried out in order to find the interference. A placebo blank consisting of $20 \mathrm{mg}$ sodium alginate, $30 \mathrm{mg}$ magnesium stearate, $20 \mathrm{mg}$ lactose, $20 \mathrm{mg}$ acacia, $50 \mathrm{mg}$ talc and $30 \mathrm{mg}$ starch but without $S M T$ was prepared and analyzed as described under "procedure for tablets". There was absolutely no interference from the placebo in method A but huge interference was encountered in method $\mathrm{B}$. The interference from placebo mixture in method B was successfully overcome by extraction of $S M T$ into chloroform and by performing the analysis as described under tablets.

\section{Application to analysis of pharmaceutical formulations}

Method A does not suffer from interference from the tablet excipients and results in Table III show close agreement between the results obtained by the proposed methods and the label claim. Method B entails extraction of SMT into chloroform since there was some interference from the excipients when applied directly to the tablet extract in $\mathrm{NaOH}$. The chloroform was later evaporated and residue was dissolved in $\mathrm{NaOH}$ where an appropriate working concentration of SMT was prepared and analyzed as given under assay procedure for tablets. The results were compared statistically by applying Student's t-test for accuracy and the variance ratio $\mathrm{F}$-test for precision with results from the literature method (Arayne et al., 2007) at a 95\% confidence level. The calculated t-test and F-values (Table III) did not exceed the tabulated values of 2.37 and 6.39 , respectively, indicating no significant difference

TABLE II - Intra-day and Inter-day precision and accuracy evaluation

\begin{tabular}{|c|c|c|c|c|c|c|c|}
\hline \multirow[t]{2}{*}{ Method } & \multirow{2}{*}{$\begin{array}{c}S M T \\
\left(\times 10^{-5}\right. \\
\mathrm{mol} / \mathrm{L}) \\
\text { taken }\end{array}$} & \multicolumn{3}{|c|}{ Intra-day $(\mathrm{n}=7)$} & \multicolumn{3}{|c|}{ Inter-day $(\mathrm{n}=5)$} \\
\hline & & $\begin{array}{c}S M T \\
\left(\mathrm{x} 10^{-5} \mathrm{~mol} / \mathrm{L}\right) \\
\text { found }^{\mathrm{a}} \\
\end{array}$ & Precision $^{b}$ & Accuracy $^{\mathrm{c}}$ & $\begin{array}{c}S M T \\
\left(\times 10^{-5} \mathrm{~mol} / \mathrm{L}\right) \\
\text { found }^{\mathrm{a}}\end{array}$ & Precision $^{\mathrm{b}}$ & Accuracy ${ }^{c}$ \\
\hline \multirow[t]{3}{*}{$\bar{A}$} & 2.94 & 2.98 & 1.15 & 1.56 & 2.99 & 1.85 & 1.72 \\
\hline & 8.83 & 8.99 & 1.82 & 0.97 & 8.96 & 1.51 & 1.34 \\
\hline & 14.72 & 14.95 & 1.57 & 0.58 & 15.00 & 1.95 & 0.98 \\
\hline \multirow[t]{3}{*}{ B } & 0.45 & 0.46 & 2.00 & 1.83 & 0.47 & 1.00 & 2.15 \\
\hline & 1.36 & 1.37 & 0.83 & 1.26 & 1.37 & 1.58 & 1.58 \\
\hline & 2.26 & 2.28 & 0.90 & 0.72 & 2.28 & 0.70 & 0.84 \\
\hline
\end{tabular}

a. Mean \pm Mean value of $\mathrm{n}$ determinations, b. Relative standard deviation (\%), c. Bias \%: $\frac{\text { found }- \text { taken }}{\text { taken }} \times 100$. 
TABLE III - Results of assay of tablets and statistical evaluation

\begin{tabular}{|c|c|c|c|c|}
\hline \multirow{2}{*}{$\begin{array}{l}\text { Tablet brand } \\
\text { name** }\end{array}$} & \multirow{2}{*}{$\begin{array}{l}\text { Nominal amount } \\
\mathrm{mg}\end{array}$} & \multicolumn{3}{|c|}{ Found (\% of nominal amount $\pm \mathrm{SD}$ )* } \\
\hline & & Literature method $^{* * *}$ & Method A & Method B \\
\hline \multirow[t]{6}{*}{ Simvofix ${ }^{\mathrm{a}}$} & 20 & $99.64 \pm 0.78$ & $98.85 \pm 1.26$ & $100.14 \pm 0.74$ \\
\hline & & & $\mathbf{t}=1.22$ & $\mathbf{t}=1.04$ \\
\hline & & & $\mathbf{F}=2.60$ & $\mathbf{F}=1.11$ \\
\hline & 40 & $102.50 \pm 0.62$ & $103.10 \pm 0.96$ & $101.80 \pm 0.36$ \\
\hline & & & $\mathbf{t}=1.20$ & $\mathbf{t}=2.26$ \\
\hline & & & $\mathbf{F}=2.40$ & $\mathbf{F}=2.97$ \\
\hline \multirow[t]{6}{*}{ Zosta $^{\mathrm{b}}$} & 10 & $97.62 \pm 0.86$ & $98.74 \pm 1.65$ & $96.83 \pm 1.11$ \\
\hline & & & $\mathbf{t}=1.41$ & $\mathbf{t}=1.48$ \\
\hline & & & $\mathbf{F}=3.68$ & $\mathbf{F}=1.67$ \\
\hline & 20 & $100.30 \pm 0.58$ & $101.00 \pm 1.42$ & $99.78 \pm 1.26$ \\
\hline & & & $\mathbf{t}=1.10$ & $\mathbf{t}=0.89$ \\
\hline & & & $\mathbf{F}=5.99$ & $\mathbf{F}=4.72$ \\
\hline
\end{tabular}

*Mean value of five determinations. ${ }^{* *}$ Marketed by: a. Bal Pharma (Servetus); b. USV (Corvette). Tabulated t-value at the $95 \%$ confidence level is 2.77; Tabulated F-value at the 95\% confidence level is 6.39. ${ }^{* * *}$ Arayne et al. 2007

TABLE IV - Results of recovery study by standard addition method

\begin{tabular}{|c|c|c|c|c|c|c|c|c|}
\hline \multirow{2}{*}{$\begin{array}{l}\text { Formulation } \\
\text { studied }\end{array}$} & \multicolumn{4}{|c|}{ Method A } & \multicolumn{4}{|c|}{ Method B } \\
\hline & $\begin{array}{l}S M T \text { in } \\
\text { tablet } \\
\left(\mathrm{x} 10^{-5}\right. \\
\mathrm{mol} / \mathrm{L}) \\
\end{array}$ & $\begin{array}{c}\text { Pure } S M T \\
\text { added, } \\
\left(\times 10^{-5}\right. \\
\mathrm{mol} / \mathrm{L})\end{array}$ & $\begin{array}{l}\text { Total } \\
\text { found, } \\
\left(\times 10^{-5}\right. \\
\mathrm{mol} / \mathrm{L})\end{array}$ & $\begin{array}{c}\text { Pure } S M T \\
\text { recovered*, } \\
\text { Percent } \pm \text { SD }\end{array}$ & $\begin{array}{l}S M T \text { in } \\
\text { tablet, } \\
\left(\times 10^{-6}\right. \\
\mathrm{mol} / \mathrm{L})\end{array}$ & $\begin{array}{c}\text { Pure } S M T \\
\text { added, } \\
\left(\mathrm{x} 10^{-6}\right. \\
\mathrm{mol} / \mathrm{L})\end{array}$ & $\begin{array}{c}\text { Total } \\
\text { found, }(\mathrm{x} \\
\left.10^{-6} \mathrm{~mol} / \mathrm{L}\right)\end{array}$ & $\begin{array}{c}\text { Pure } S M T \\
\text { recovered*, } \\
\text { Percent } \pm \text { SD }\end{array}$ \\
\hline \multirow{4}{*}{$\begin{array}{l}\text { Zosta, } \\
20 \mathrm{mg}\end{array}$} & 6.86 & 3.39 & 10.30 & $101.40 \pm 1.28$ & 9.04 & 4.53 & 13.52 & $99.00 \pm 0.76$ \\
\hline & 6.86 & 6.79 & 13.90 & $103.70 \pm 1.76$ & 9.04 & 9.06 & 17.85 & $97.25 \pm 1.04$ \\
\hline & 6.86 & 10.19 & 17.12 & $100.70 \pm 1.12$ & 9.04 & 13.59 & 22.04 & $95.67 \pm 0.85$ \\
\hline & 7.00 & 3.39 & 10.57 & $103.20 \pm 0.85$ & 9.22 & 4.53 & 13.77 & $100.50 \pm 0.64$ \\
\hline \multirow{2}{*}{$\begin{array}{l}\text { Simvofix, } \\
40 \mathrm{mg}\end{array}$} & 7.00 & 6.79 & 14.02 & $103.30 \pm 0.74$ & 9.22 & 9.06 & 18.59 & $103.50 \pm 1.02$ \\
\hline & 7.00 & 10.19 & 17.35 & $101.40 \pm 1.20$ & 9.22 & 13.59 & 22.97 & $101.20 \pm 0.86$ \\
\hline
\end{tabular}

*Mean value of three determinations

between the proposed methods and the reference method in terms of accuracy and precision. The validity of the methods was confirmed by applying the standard addition technique. Pre-analyzed tablet powder containing SMT was spiked with pure $S M T$ at three concentration levels and the totals were found by the proposed methods. Each determination was done three times. The results of this study are compiled in Table IV.

\section{CONCLUSIONS}

Two simple, rapid, fairly accurate and precise, and sensitive spectrophotometric methods were developed for the determination of SMT in bulk drug and in tablets. The methods are free from rigid experimental conditions and are characterized by wide linear dynamic ranges and high sensitivity, and employ inexpensive and easily available chemicals. The low detection and quantification limits, simplicity and selectivity make the method suitable for quality control in the pharmaceutical industry for routine analysis. However, method B entails an extraction step when applied to tablets to overcome the interference from some inactive ingredients.

\section{ACKNOWLEDGEMENT}

Authors thank M/S. Jubiliant Organosis, Mysore, for providing the gift of pure simvastatin. Three of the authors (KT, NRP, KBV and SGH) thank the authorities of the University of Mysore, Mysore, for permission and facilities. Kalsang Tharpa also thanks the Department of Education, Central Tibetan Administration of His Holiness the Dalai Lama, for providing a research scholarship. 


\section{REFERENCES}

ALI, A.; NAMEH, E. S. M.; SHAWABKEH, R. A. Highperfromance liquid chromatographic determination of simvastatin in medical drugs. J. Anal. Chem., v.61, p.6366, 2006.

ARAYNE, M. S.; SULTANA, N.; HUSSAIN, F.; ALI, S. A. Validated spectrophotometric method for quantitative determination of simvastatin in pharmaceutical formulations and human serum. J. Anal. Chem., v.62, p.536-541, 2007.

CHANDHARI, B.G.; PATEL, N. M.; SHAH, P. B. Determination of simvastatin, pravastatin sodium and rosuvastatin calcium in tablet dosage forms by HPTLC. Indian J. Pharm. Sci., v.69, p.130-132, 2007.

CAROLINA, G.; GLORIA, G. C.; MARTA, D. D.; RICARDO, G. Liquid chromatography for fast determination of simvastatin in drug substance. J.Chilean Chem. Soc., v.49, p.289-290, 2004.

CARLCUCCI, G.; MAZZEO, P., Determination of simvastatin in pharmaceutical forms by HPLC and derivative UVspectrophotometry. Farmaco, v.47, p.817-823, 1992.

CORUH, O.; OZKAN, S. A. Determination of the antiperlipidemic simvastatin by various voltammetric techniques in tablets. Die Pharmazie, v.61, p.285-290, 2006.

ERK, N. Rapid spectrophotometric method for quantitative determination of simvastatin and fluvastatin in human serum and pharmaceutical formulations. Pharmazie, v.57, p.817-819, 2002.

INTERNATIONAL CONFERENCE ON HARMONISATION. ICH Technical requirements for registration of pharmaceuticals for human use. Harmonised Tripartite Guideline. Validation of analytical procedures: text and methodology Q2(R1). Complementary Guideline on Methodology. Washington, DC, 1996. 13 p.

JIANWEI, X.; YING, L. HPLC determination of simvastatin and its related substances. Yaowu Fenxi Zazhi, v.25, p.523-525, 2005.

MANN, F. G.; SOUNDERS, B. C. Practical organic chemistry. 4.ed. Cambridge: Longman, 1974. p.85.

MC EVOY, G. K. HFS Drug information. Bethesda, MD: American Society of Health System Pharmacists, 2002. p.779-782.
THE UNITED STATE PHARMACOPOEIA. National Formulary 20. Rockville, MD: United States Pharmocopocial Convention Inc., 2002, p.9571-9572.

SHABIR, G.A. Validation of high-performance liquid chromatography methods for pharmaceutical analysis: understanding the differences and similarities between validation requirements of the US Food and Drug Administration, the US Pharmacopeia and the International conference on Harmonization. J. Chromatogr. A., v.987, p.57-66, 2003.

SRINIVASU, M. K.; RAJU, A. N.; REDDY, G. O. Determination of lovastatin and simvastatin in pharmaceutical dosage forms by MEKC. J. Pharm. Biomed. Anal., v.29, p.715721, 2002.

SARADHI, S. V.; HIMABINDU, V.; RAO, G. V. Spectrophotometric methods for the determination of simvastatin. Acta Cienc. Indica, v.33, p.205-208, 2007.

WANG, L.; ASGHARNEJAD, M. Second-derivative UV spectrometric determination of simvastatin in its tablet dosage form. J. Pharm. Biomed. Anal., v.21, p.1243-1248, 2000.

WANG, J. HPLC determination of simvastatin in tablets. Zhongguo Yiyao Gongye ZaZhi, v.31, p.121-122, 2000; Sci Finder, CAN 132:284323; AN 2000:293986.

XAN, X.; CAO, G.; HE, X.; HU, X.; GU, D. Determination of simvastatin by HPLC. Huaxi Yaoxue Zazhi, v.15, p.205206, 2000.

XU, L., Determination of simvastatin in tablets by UV spectrophotometry. Thongguo Yiyao Gongye Zazhi, v.32, p.271-272, 2001; Sci. Finder CAN 135:362691;AN 2001: 606960 .

YAN, X.; CAO, G.; HE, X.; HU, X.; GU, D.; Determination of simvastatin by HPLC. Huaxi Yaoxue Zazhi, v.15, p.205206, 2000

ZHONGHONG, L.; SHURONG, T. Quantification determination of simvastatin in capsules by first derivative spectrophotometry. Zhongguo Yaoxue Zazhi (Beijing), v.35, p.554-556, 2000.

Received for publication on $31^{\text {st }}$ July 2008 Accepted for publication on $19^{\text {th }}$ November 2009 